\title{
Гибриды моркови для товарного производства
}

\section{А.Н. Ховрин, М.А. Косенко, А.В. Корнев, Л.М. Соколова}

Представлены материалы по гибридам моркови столовой отечественной селекции, отвечающие современным требованиям товарного производства и конкурентоспособные с зарубежными аналогами: $F_{1}$ Алтаир, $F_{1}$ Бейби и др. Гибрид $F_{1}$ Бейби в 2017-2018 годах проходил производственные испытания в крупнейшем овощеводческом товарном хозяйстве ЗАО «Куликово» (Дмитровский район Московской области) на площади 10 га и показал высокий результат по урожайности и товарности.

Ключевые слова: морковь столовая, товарное производство, $F_{1}$ Алтаир, $F_{1}$ Бейби.

$\mathrm{B}$ текущих внешнеэкономических условиях самообеспеченность продуктами питания остается приоритетной задачей [1]. Объем производства овощной продукции в последние 6-7 лет стабилизировался и составляет немногим более 16 млн т, и вместе с импортом в большей части покрывает потребность населения. Однако ассортимент продукции очень узкий, 2/3 валовой продукции обеспечивается 5-6 культурами, из более 100 окультуренных видов [2].

Из года в год растет потребление моркови, и, соответственно, растет спрос. Если раньше потребитель не требовал высокого качества моркови и был готов сам дорабатывать ее,

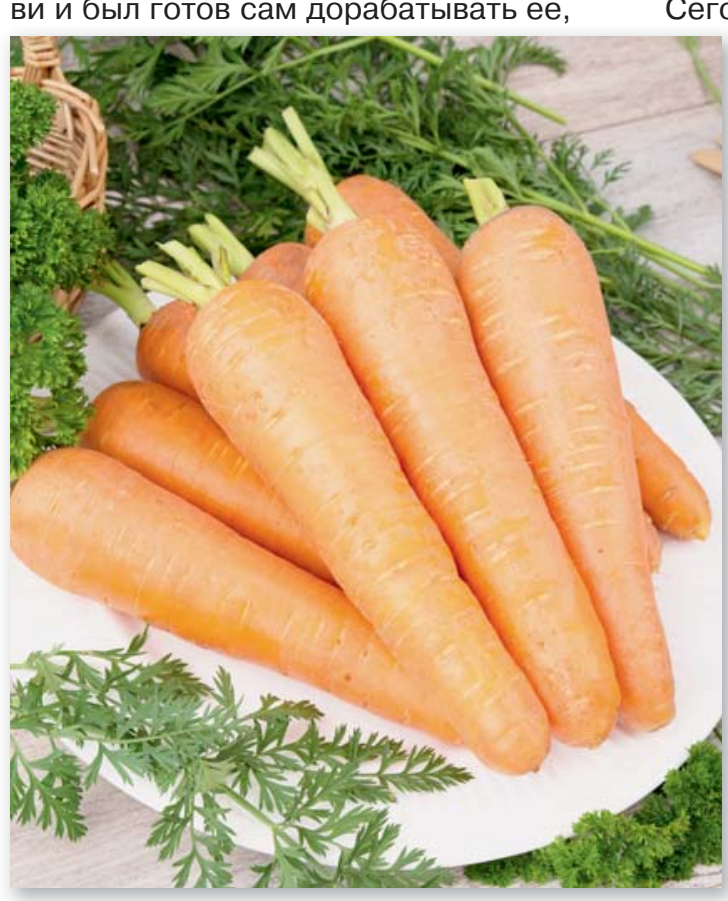

Рис. 1. $F_{1}$ Алтаир то сейчас покупатель требует, помимо мытой, шлифованной и упакованной моркови: ровный, красивый корнеплод с насыщенной оранжевой окраской. Санкции дали нам возможность заменить качественный импортный продукт на отечественный, и мы должны этим воспользоваться.

Производство моркови столовой в России - развитая сфера. Общая площадь под морковью - 70000 га, из них 30000 га в товарных хозяйствах [3]. Большая часть этой площади представлена зарубежными гибридами фирм: «Бейо» $\left(F_{1}\right.$ Каскад, $F_{1}$ Нандрин, $F_{1}$ Канада, $F_{1}$ Балтимор), «Монсанто» ( $F_{1}$ Абако), «Райк Цваан» ( $F_{1}$ Фидра, $F_{1}$ Морелия).

Сегодня, помимо государственных НИИ, оригинаторами сортов официально являются многие семеноводческие с.-х. предприятия, частные лица. Селекционносеменоводческие компании, ведущие собственную селекцию, разрабатывают авторские схемы и методы оригинального и элитного производства. С учетом того, что сегодня, при глобализации рынка семян овощных культур, в странах с подходящими для формирования семян климатическими условиями (Франции, Италии, КНР и др.) появились компании, специализирующиеся на выращивании семян высших репродукций, в том числе и линейного материала. При этом, для гарантии защиты интеллектуальной собственности, большая часть компаний выращивает оригиналь- ные и элитные семена особенно коммерчески значимых сортов и гибридов на собственных базах [4].

Цель работы - представление новых гибридов моркови столовой отечественной селекции, отвечающих современным требованиям товарного производства и конкурентоспособных с зарубежными аналогами.

В России селекцией и семеноводством моркови столовой наиболее продуктивно занимаются как государственный научно-исследовательский институт: ФГБНУ «Федеральный научный центр овощеводства» (ФГБНУ ФНЦО), так и частные компании: Агрохолдинг «Поиск», ООО «Селекционная станция имени Н.Н. Тимофеева» и др. Так, у ФГБНУ ФНЦО есть целая линейка гибридов моркови, отвечающие современным требованиям товарного производства: $F_{1}$ Алтаир, $F_{1}$ Бейби (совместной селекции с Агрохолдингом «Поиск»), $F_{1}$ Таврида, $F_{1}$ Надежда, $F_{1}$ Марс, $F_{1}$ Каллисто, $F_{1}$ Топаз и др.

В данной статье мы представляем два гибрида, прошедших производственные испытания и оценку в крупнотоварных хозяйствах Московской области. Назовем основные достоинства лидеров. $F_{1}$ Алтаир (рис. 1) - высокоурожайный гибрид. Среднеспелый, период от всходов до уборки урожая 100110 дней. Корнеплоды гладкие, цилиндрические с тупым кончиком, Нантского сортотипа), длиной 1822 см, насыщенная оранжевая окраска, отличный иммунитет, не подвержен заболеваниям, высокая стандартность продукции (85-90\%), устойчивость к ломкости и растрескиванию, отлично хранится, вплоть до нового урожая. Гибрид характеризуется стабильной урожайностью (5070 т/га). Рекомендуемая густота посева: для переработки и хранения 0,8-1,0 млн шт/га, для потребления в свежем виде и пучковой продукции: 1,0-1,4 млн шт/га. При ранневесеннем посеве можно использовать для получения пучковой продукции. Содержание сухого вещества 10,5$15,5 \%$, сахаров $5,5-9,5 \%$, каротина 14,5-18,5 мг на 100 г сырого вещес- 


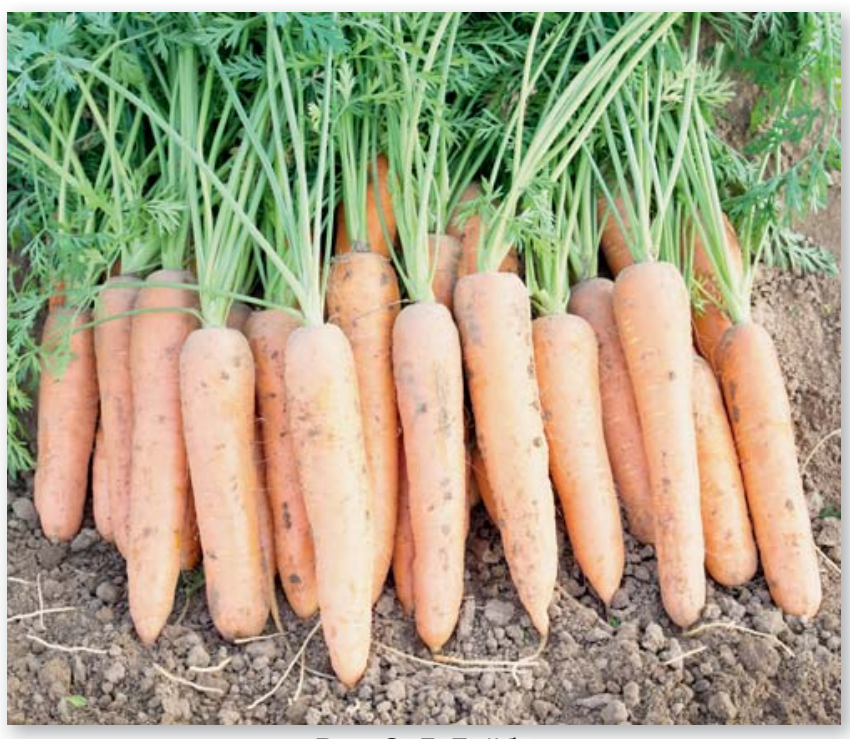

Рис. 2. $F_{1}$ Бейби

тва. $F_{1}$ Алтаир - довольно известный и популярный гибрид (ему более 25 лет). Это то, с чего можно начинать производство моркови, предназначенной для длительного хранения. Но время не стоит на месте, и наши селекционеры вывели гибрид $F_{1}$ Бейби. Он отличается от $F_{1}$ Алтаир более сильным креплением ботвы к корнеплоду, что позволяет использовать его в более жестких условиях. Гибрид устойчив к альтернориозу и фузариозу. В России из-за интенсивного земледелия идет накопление болезней, поэтому выведение новых устойчивых гибридов становится более результативным, чем применение повышенных доз фунгицидов.

$F_{1}$ Бейби (рис. 2, 3) - среднеспелый гибрид, корнеплоды ярко оранжевой окраски, с нежной, сочной мякотью, великолепного вкуса. рого вещества.
Отличается высокой товарностью и однородностью корнеплодов. Пригоден для сухой мойки и фасовки [5].

Р о с с и й с к и й гибрид. Сортотип Берликум/Нантская. Период от всходов до уборки урожая 90100 дней. Корнеплод цилиндрический, длиной 18-20 см, с тупым кончиком. Гибрид универсальный, рекомендуется для использования в свежем виде и подходит для зимнего хранения. Предпочитает песчаные и легкие суглинистые, слабокислые, хорошо аэрированные почвы. $F_{1}$ Бейби - идеальный гибрид для приготовления соков, салатов, подходит для заморозки, прекрасно смотрится в упаковке и после мойки. Содержание сухого вещества 10,5-16,0\%, сахаров 8,5$10,5 \%$, каротина до 25 мг на 100 г сы-

Рекомендуемая густота посева: для переработки: 0,7-0,9 млн шт/га, для хранения и потребления в свежем виде: 1,0-1,2 млн шт/га.

Гибрид моркови столовой $\mathrm{F}_{1}$ Бейби в 2017, 2018 годах проходил производственные испытания в крупнейшем овощеводческом товарном хозяйстве ЗАО «Куликово» (Дмитровский район Московской области) на площади 10 га. Показал высокий результат по урожайности и товарности. Товарная урожайность - 530-717 ц/га. Выход товарной продукции - 85-90\%.

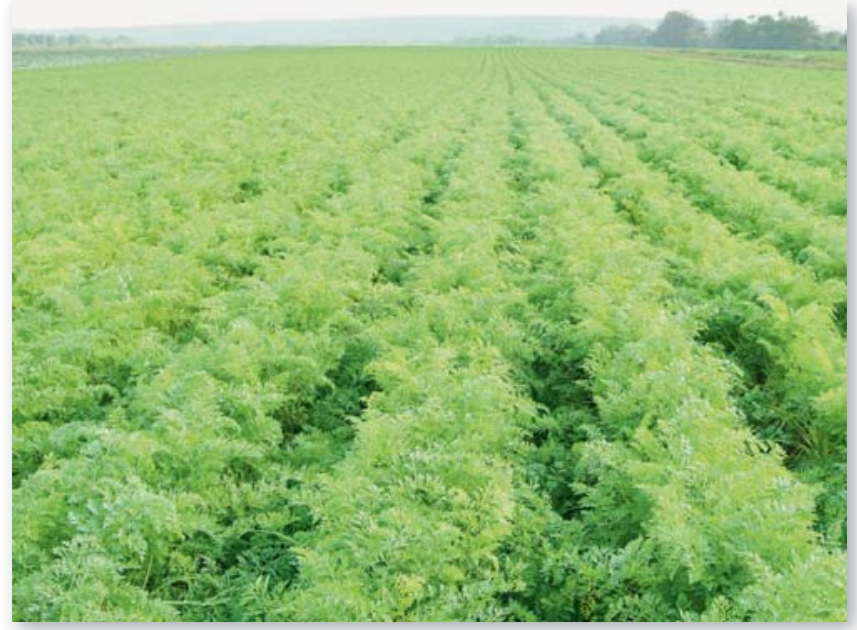

Рис. 3. Производственные испытания $F_{1}$ Бейби

Библиографический список

1.Овощи в системе обеспечения продовольственной безопасности России / А.В. Солдатенко, А.Ф. Разин, В.Ф. Пивоваров, М.В. Шатилов, М.И. Иванова, О.В. Россинская, О.А. Разин // Овощи России. 2019. № 2 (46). C. 9-15.

2.Пивоваров В.Ф., Солдатенко А.В., Мусаев Ф.Б. Современные темпы развития овощеводства в РФ // Труды Кубанского государственного аграрного университета. 2018. № 72. С. 293-298.

3.Леунов В.И. Направления в селекции и семеноводстве овощных корнеплодных культур // Картофель и овощи. 2017. №10. C. 6-9.
4.Ховрин А.Н., Ибрагимбеков М.Г., Багров Р.А. Оригинальное семеноводство овощных корнеплодных культур в Московской области // Картофель и овощи 2018. № 2. С. 34-36.

5.Отечественные сорта и гибриды для торговых сетей / О.В. Бакланова, О.Р. Давлетбаева, М.Г. Ибрагимбеков, М.А. Косенко, Г.А. Костенко, Т.А. Терешонкова, Л.Н. Тимакова, Л.А. Чистякова, А.Н. Ховрин // Картофель и овощи. 2018. № 10. С. 2-7.

\section{Об авторах}

Ховрин Александр Николаевич, канд. с. -х. наук, доцент, зав. отделом селекции и семеноводства, Всероссийский НИИ овощеводствафилиал ФГБНУ «Федеральный научный центр овощеводства» (ВНИИОфилиал ФГБНУ ФНЦО), руководитель службы селекции и первичного семеноводства, Агрохолдинг «Поиск».

E-mail: hovrin@poiskseeds.ru

Косенко Мария Александровна, канд. с. -х. наук, с.н.с отдела селекции и семеноводства, ВНИИО-филиал ФГБНУ ФНЦО.

E-mail: m.a.kosenko@yandex.ru

Корнев Александр Владимирович, канд. с. -х. наук, н.с. отдела селекции и семеноводства, ВНИИО-филиал ФГБНУ ФНЦО

Соколова Любовь Михайловна, канд. с. -х. наук, с.н.с отдела селекции и семеноводства, ВНИИО-филиал ФГБНУ ФНЦО

Hybrids carrots for commercial production

A.N. Khovrin, PhD, associate professor, chief research fellow, head of department of breeding and seed growing of ARRIVG branch of FSBSI FSVC, head of department of breeding and primary seed production of Poisk Agro Holding.

E-mail: hovrin@poiskseeds.ru

M.A. Kosenko, PhD, senior research fellow, department of breeding and seed production, ARRIVG-FSBSI FSVC.

E-mail:m.a.kosenko@yandex.ru A.V. Kornev, PhD, research fellow, department of breeding and seed production, ARRIVG-FSBSI FSVC L.M. Sokolova, $P h D$, senior research fellow, department of breeding and seed production, ARRIVG-FSBSI FSVC

Summary. There are presented materials on carrots hybrids of domestic breeding that meet modern requirements of commodity production and are competitive with foreign analogues: $F_{1}$ Altair, $F_{1}$ Beibi and others. Hybrid $F_{1}$ Beibi in 2017-2018 passed production tests in the largest vegetable-growing commodity economy of CJSC Kulikovo (Dmitrovo district of the Moscow region) on the area of 10 ha and showed high result on productivity and marketability.

Keywords: carrots, commercial production, $F_{1}$ Altair, $F_{1}$ Beibi. 